\title{
BRITISH ENTERPRISE ZONES: A CRITICAL ASSESSMENT
}

\author{
William D. Gunther and Charles G. Leathers*
}

\section{Introduction}

In its second term, the Reagan administration has continued to press Congress for legislation to implement a program of enterprise zones. While the proposed federal program has advocates both within and outside the administration, critical analyses by economists and urban policy specialists have raised questions about the potential impacts of enterprise zones on urban areas (see, for example, Botham and Lloyd, 1983; Gunther and Leathers, 1981; Ford, 1983; Hawkins, 1984; and Malone, 1982). Until recently, such analyses had to proceed on a largely theoretical basis. Reports on early developments in the first 11 British enterprise zones, however, now provide an empirical basis for initiating critical assessments of the concept.

In the following section of this paper, we review the original concept of enterprise zones and note the major features of the actual program implemented by the British government in 1981. The third section provides a profile of the major features of and developments in the first (and largest) British enterprise zone at Swansea, Wales. In the fourth section, we analyze data drawn from the official monitoring report on the first 11 British enterprise zones during their first two years of operation. Our attention focuses on the number of firms entering the zones, their origins and motives for locating in the zones, the number of jobs involved and sources, and the public cost involved in developing and promoting the zones.

There are, of course, severe limitations imposed by the data available, both in terms of the limited time period covered and the type and amount of information provided by the monitoring reports. With respect to the limited time of actual operational experience of the zones however, the pace of development during the first two years (1981-1983) is probably more significant than it might first appear. Benefits to firms operating in the zones run concurrently with the

*Professors of Economics, The University of Alabama. The authors gratefully acknowledge financial assistance provided by the Research Grants Committee and the Office of International Programs, The University of Alabama. designated life of the zone (10 years). Consequently, firms entering the zones after the first two years will receive substantially less benefits. It was recognized by proponents of the British program that developments during the first three years would be the critical period (Financial Times, 1983).

\section{The British Enterprise Zone Program}

Enterprise Zones were the conceptual creation of Peter Hall, a British urbanologist (Professor of geography at Reading University) who visited the Far East in 1977 and was struck by the economic successes of Singapore and Hong Kong (see Butler, pp. 96-98). Critical of the traditional policies for revitalizing decaying inner-city areas, Hall (a former chairman of the socialist Fabian Society) suggested a new "freeport" approach:

... a radically different kind of regime, outside the scope of UK customs or legislation, with free movement of labour and capital: a genuine mini Hong Kong in some derelict corner of the London or Liverpool docklands, representing an experimental alternative to the mainstream British economy (Hall, 1984).

The program of enterprise zones actually implemented by the Thatcher government in 1981, however, was substantially different from Hall's original proposal. The program stemmed largely from the interest and efforts of Sir Geoffrey Howe, Thatcher's first Chancellor of the Exchequer. In 1978, before the Conservative party came to power, Howe had proposed the creation of small areas in depressed inner-cities in which taxes and governmental regulations would be largely eliminated and government services reduced to a minimum (Howe, 1981). His premise was that with the economic environment freed of governmental restrictions and taxes, pent-up private entrepreneurial activities would blossom forth into new firms and new jobs in those derelict areas. Enterprise zones were formally proposed as government policy in Howe's 1980 budget speech, and were implemented by the Local Government, Planning and Land Act of 1980 (Botham and Lloyd, p. 25). 
Enterprise zones were designated for a period of 10 years. The geographic areas of the zones ranged in size from less than 100 acres to 735 acres. Business firms operating in enterprise zones were provided the following incentives: (1) exemption from rates, i.e., property taxes, on industrial and commercial property; (2) 100 percent allowances against corporation and income taxes for capital outlays on industrial and commercial buildings, the so-called IBAs; (3) exemption from the development land tax; (4) exemption from industrial training levies and the need to supply information to industrial training boards; (5) simplified planning and regulatory procedures; and (6) priority in processing certain customs facilities (Tym, 1984, p. 1).

The designated zones have certain common features, namely: (1) they are small sites that constitute only portions of labor and property markets; (2) they are generally unoccupied or largely underutilized areas; (3) they had been damaged by previous generations of economic activities; (4) they are located in economic problem areas, although the scale of those problem areas varies considerably; and (5) public sector development agencies were already heavily involved in these areas prior to zone designation (Tym, 1984, pp. 78). The program was officially chacterized as an experiment and not an integral part of Britain's regional policy. Armstrong and Taylor (1985) have commented that the proposed enterprise zones:

are so much at odds with traditional regional policy that they deserve car eful consideration. If they were found to be successful, they would provide the policy maker not simply with a new policy instrument but would challenge the entire rationale underlying traditional regional policy (p. 222).

Armstrong and Taylor conceded that the actual program only faintly resembled the original concept by Peter Hall and was not substantially different from traditional regional policy. Even Hall (1984) observed that, "These incentives are strangely reminiscent of the traditional clutch of regional incentives that have operated in the assisted areas ever since 1945."

Clearly, the enterprise zones are a far cry from the "freeport" concept advanced by Hall. Nor are the regulations substantially reduced. The main incentives are the tax advantages gained by firms entering the zones, which are similar to the approach traditionally referred to as indicative planning. The 10-year exemption from local property taxes bears a very close resemblance to the practice of a number of states in the United States of exempting property taxes for firms. It is interesting to note that the public policy objective to be served by the enterprise zone program has been stated somewhat differently by different sources. An interpretation offered by The Economist appeared to comport with the original idea of enterprise zones. Accordingly, the program was designed to accomplish three related objectives: (1) to stimulate the regeneration of inner-city "wildernesses;" (2) to assist the development of small businesses in those areas; and (3) to encourage new employment opportunities (The Economist, 1980).

The introductory brochure issued by the British Department of the Environment, which administers the enterprise zones, states the purpose more cautiously:

The idea is to see how far industrial and commercial activity can be encouraged by the removal of certain tax burdens, and by relaxing or speeding up the application of certain statutory or administrative controls (Tym, 1984, p. 1).

The monitoring report defines the general objective of the British enterprise zone policy in the following terms: to promote the development and productive use by the private sector of the designated sites and thereby to generate wider benefits, such as a net increase in economic activity in areas very much larger than the enterprise zones themselves, and contributions to town and country planning or other objectives (Tym, 1984, p. 141).

Further, the report identifies the policy strategy as one of stimulating productive activity and employment through an improved supply of land and premises.

This serves to effectively accentuate the difference between the original concept of the enterprise zones as "freeports" in which private entrepreneurs would be freewheeling catalysts of economic progress. Emphasis on part of the British program has been to redevelop property, with a major role to be played by public authorities in the initial service of land and the provision of appropriate infrastructure improvements. In contrast, the original concept emphasized that properties would be developed by private entrepreneurs free of any government restrictions or taxes. Moreover, it must be noted that the British policy emphasizes land use rather than creation of jobs or neighborhood community redevelopment, as American proponents of enterprise zones have been quick to point out (Butler 1981, pp. 123-127; and Weiner, 1984). 


\section{The Swansea Enterprise Zone: A Profile}

While there is no "typical" British enterprise zone, it may be useful to profile one particular zone. The Swansea Enterprise Zone was the first zone to receive official designation and is the largest of the first 11 zones. Moreover, it is frequently cited as an example of the viability of the program in light of the number of firms operating in the zone and the number of people employed by those firms (see, for example, The Director, 1985).

Some critics have charged that Swansea was deliberately selected to receive an enterprise zone because a high level of development was virtually assured due to its favorable location and the efforts already underway by local authorities to develop the area. Swansea is the second largest city in Wales, with a population of roughly 200,000 . Urban pressure in the city is relatively mild, with the density of population only about one-fifth of that found in other British urban areas. In addition, the number of college-educated and highly skilled people per 1,000 population exceeds the average of other British cities (Swansea City Council, 1985c).

Located on Swansea Bay and serving as the regional administrative center for southwestern Wales, Swansea is about 45 miles from Cardiff, Wale's largest city. It is located near rail lines and the M4 motorway, which facilitates rapid transportation to both London and the industrial midlands city of Birmingham. During the 19th century Swansea was the world center for the production of non-ferrous metals. In the 20th century, Swansea experienced steady economic decline and by the 1970s had become an economically distressed area. For some years prior to the designation of the enterprise zone, both the Swansea local council and the Welch Development Agency had been working in the clearance of the Lower Swansea Valley. Major land reclamation and improvement projects had been funded by grants from the European Regional Development Fund, the Welch Development Agency, the Welch Office, Land Authority for Wales, and Swansea City Council funds. Consequently, a large amount of good industrial land was available even before the zone was designated (Financial Times, 1983b).

Swansea already was designated as an "assisted area" under British regional policy under its classification as Development Area status. Local officials had been described as being "particularly forward looking" in the promotion of its economic strategy, and the Swansea Trade and Industry Centre provided a variety of schemes aimed at promoting the published by the City in 1974 . Work already prosperity of smaller firms (Financial Times, 1983b). Development in Swansea was guided by informal plans undertaken to create attractive economic and social enviroments in Swansea had resulted in the Valley being selected as one of five UK demonstration sites in the European Campaign for Urban Renaissance (Swansea City Council, 1985c, p. 6).

The enterprise zone, officially designated as the Lower Swansea Valley Enterprise Park, covers 775 acres of mostly level land approximately five miles from the coast and three miles from the city center. Part of the area consists of reclaimed industrial land, and the rest is green field land. Sites in the north of the park are in a semi-rural location while those in the south cluster around a 20 acre lake. Wide landscaping belts are laid out and maintained by the Council, which is the principal landowner. The zone or park has been laid out in accordance with the high environmental standards of a low density industrial park in Britain (Swansea City Council, 1985c, pp. 6-7).

There is a special meaning to the use of the word "park". Local officials stress that the word "park," as opposed to the more traditional term "industrial estate," reflects two basic factors inherent in the development principles being applied. First, modern firms require a consistently high standard of development in order to protect and enhance the value of their capital investments. Second, people working in industry now expect good environmental conditions both inside and outside their workplaces (Swansea City Planning Department, 1983). Obviously, these are a far cry from the original concept of entrepreneurial freedom espoused by Hall in the original concept of enterprise zones.

The Swansea enterprise zone is one of five parks developed within the lower Swansea Valley in accordance with the published informal plans. These are separate but inter-related parks running throughout the length of the lower Swansea Valley, with the river Tawe as the common link.

The M4 motorway is adjacent to the northern boundary of the Swansea Enterprise Park. The main London-Swansea rail line forms the southern boundary of the park, while the regional freight railroad line forms the northem boundary. British Rail and the City Council have agreed to promote the development of a road/rail modal transfer facility and to provide direct rail access into the zone. The park is three miles from the Swansea Docks, five miles from Swansea Airport, 40 miles from the International Airport at Cardiff, and 190 miles from London's Heathrow airport. The park is bounded on the south by a Leisure Park incorporating extensive forest areas and major facilities for formal recreation. Clearly, it bears little resemblance to 
derelict inner-city areas usually associated with the concept of enterprise zones.

Moreover, the Swansea Enterprise Park benefits from the designation of the Swansea Travel-to-Work Area as an Intermediate Area under the government's revised regional policy. The Assisted Area Status which this confers not only gives the local authorities access to valuable infrastructure grants but also enables firms within the area to apply for various types of financial assistance and to become eligible for various types of financial incentives not associated with the enterprise zone program. For example, sources of public funds are available to private enterprise through Swansea's designation as a Steel Closure Area and as a Designated District under the Inner Urban Areas Act of 1978. The latter designation gives access to the government's recent Urban Development Grant scheme (Swansea City Council, 1985c, p. 2).

\section{Developments in the Swansea Enterprise Park}

Data on the number of firms operating in the Swansea Enterprise Park through June 30, 1985 are now available through monitoring reports published by the Swansea City Council. During the first four years of the enterprise zone's operation, a net total of 137 firms have begun operations in the Park. The gross number of post-designation firms was 157 , with 20 either going out of business or transferring operations elsewhere. At the time of designation in June of 1981, 86 firms were operating in the zone. Of that number, 68 were still in operation as of June 30, 1985 (Swansea City Council, 1985b, pp. 2-3).

The local authorities administering the Swansea Enterprise Park count both "new start-ups" and "new branches" as new ventures, and stress that 63 percent of the post-designation firms fall into that general category. Of the 137 firms operating in the zone in June 1985, 51 firms (37 percent of the total) were "movers," having transferred operations from outside the zone to sites within the zone. Forty-six of these firms moved from Swansea locations in the zone; and 4 more moved from within Wales. One firm transferred from outside of Wales. Thirty-seven firms were "new branches," (27 percent of the total). Of these, 19 were related to Swansea firms, 13 were from outside of Wales, and 5 were from Wales. The remaining 49 firms were "new start-ups," but the data available does not indicate whether these ventures would have emerged if the zone did not exist, or if they would have emerged elsewhere in the district (Swansea City Council, 1985b, pp. 19-21).
The majority of the firms ( 68 percent) were in the service sector, with about half of those described as being in the "distributive trades" (Swansea City Council, 1985b, p. 3). The heavy concentration of retailers in the post-designation firms in the zone has created fears among the retailing community in the Swansea city center that the zone is becoming simply a retail center that threatens the viability of the rest of Swansea's retailers. Accordingly, local retailers have asked the zone authorities to prohibit any additional retail establishments in the Enterprise Park. While the authorities have rejected that request, they have taken steps to restrict the size of retailers in terms of floor space (The Director, 1985, pp. 53-54). Only 23 percent of the post-designation firms were involved in manufacturing, and the remaining 9 percent were involved in construction.

Those firms that moved into the enterprize zone from premises elsewhere offered a number of reasons for their location decisions. The surveys conducted by the zone authorities, however, give no indication of the influence of the incentives provided to firms operating in the zone. The surveys indicated that all the firms were "pushed" out of their original locations, either unable to remain there or adversely affected by doing so. All movers would have relocated somewhere, the great majority somewhere within Swansea itself. A number of firms cited the need for larger floor space and its availability in sites within the zone (Swansea City Council, 1985b, p. 36).

As of June 30,1985 , the 137 post-designation firms in the Swansea zone employed 1,616 workers. Another 184 jobs were expected to be provided by firms committed to the zone but not yet in occupancy. The zone authorities listed 759 of these (46 percent) as "new" jobs which did not exist anywhere else before the zone was designated. The other 857 jobs were listed as "transferred," 92 percent of those from within Swansea itself. In addition, several hundred construction workers were employed on zone sites during the first four years of the zone's existence. The zone authorities project that the same number will be employed for several more years as construction continues within the zone (Swansea City Council, 1985b, p. 28).

Most of the firms were small employers; only 15 employed more than 25 workers. Employment distribution by sector reflects the dominance of the service/distributive trades establishments in the zone. Manufacturing firms collectively employed only 16 percent of the 1,616 workers, while construction firms employed 12 percent. Full-time workers accounted for 82 percent of the total number of jobs; and 62 percent of the jobs were held by males. Only 68 jobs out of 
the 1,616 were transferred into the zone from outside the Swansea district. The rest were either "created" by new start-ups/new branches or transferred from with Swansea.

Employment within the zone has also been affected by developments among the pre-designation firms. As mentioned above, 18 firms operating in the zone on designation day either subsequently closed or transferred operations elsewhere. The number of jobs lost as a consequence was 287 . In addition, 224 more jobs were eliminated by redundancy among the remaining predestination firms, bringing the total job loss figure to 511. Partially off-setting that loss were 230 jobs "created" by other pre-destination firms expanding employment. Thus, a net total of 281 jobs were lost between June 1981 and June 1985, bringing the net increase in total jobs in the zone over that time to less than 1,400 (Swansea City Council, 1985b, pp. 42-43).

In 1983, some 50,000 workers were unemployed in the Swansea area and the employment rate among males reached 20 percent (Financial Times, 1983b). While the jobs "created" within the zone by new startups and new branches of firms operating outside of Swansea helped the employment problem in only a minor fashion, even that gain would be worthwhile if at a reasonable cost. As of 1983, local authorities had expended about 7 million pounds on site preparation and construction of units for lease (Tym, 1984, pp. A11A12). In addition, the public cost of the tax expenditures by the central government must be included in the overall cost of the Swansea enterprise zone. The central government had to compensate local authorities for the rate relief (property tax exemptions) granted to firms operating in the zone. The central government also lost revenues by virtue of the IBAs granted to firms investing in commercial and industrial facilities. While no data are available on the cost of these public expenditures, a very crude estimate can be made.

The monitoring report estimated that during the first two years of the operation of the first 11 zones, the public expenditure cost for the total program amounted to 17 million, while the cost of the IBAs (foregone revenues) amounted to roughly 38 million pounds (Tym, 1984, p. 94). If it is assumed that since the number of firms and employment in the Swansea zone exceeds 10 percent of the total for all 11 zones, at least 10 percent of the tax expenditure cost can be attributed to the Swansea zone, the tax-expenditures associated with this zone during the first two years would be roughly 5.5 million pounds. On that basis, the total estimated public cost would be about 13 million pounds. At a conservative exchange rate (for the period) of $\$ 2.00$ per pound, the dollar equivalent cost would be about $\$ 26$ million.

How many jobs were "created" in the Swansea zone for a public investment of $\$ 26$ million? Local authorities prefer to treat all the jobs provided by new start-ups and new branches as "new" jobs created by the presence of the zone. On that basis, the 759 jobs involved amounted to an average public investment of $\$ 34,256$ per job. But the monitoring report estimates that only 4 to 12 percent of all "new" firms (i.e., new branches and new start-ups) for all the zones can be attributed to the presence of the zones themselves (Tym, 1984, p. 144). Using the higher estimate of 12 percent and applying it to the Swansea experience, this would mean that only about 91 new jobs were actually created by the presence of the Swansea enterprise zone. The rest presumably would have emerged elsewhere in the British economy. If these figures are assumed correct, the average public investment cost per job has more than $\$ 285,000$.

In their study of the Sweansea zone, Bromley and Morgan (1985, p. 412) suggest a public cost per job of 40,000 pounds or $\$ 80,000$. This only serves to indicate the diffficulty of estimating both the number of jobs "created" and the public cost involved. Clearly, however, the various estimates do indicate that the cost has not been insignificant.

\section{General Experiences of the British Enterprise Zone}

The Department of the Environment commissioned a three-year monitoring study of the first-generation enterprise zones. The third-year report by Tym and Partners (1984) actually covered only the first two years of operational developments in the zones, i.e., from June 1981 through May 1983. As noted earlier, having data for such a limited time period does not necessarily reduce the ability to make assessments about the viability of the program, since it was recognized that the first three years of developments in the zones would be critical. While the data on the impact of the incentives provided by the enterprise zones on the creation of entrepreneurial ventures and jobs are severly limited, some interesting information is provided by the monitoring report on the number of firms entering the zones, the source of those firms ("new firms" vs. "movers"), the number of jobs, the industrial/ commercial classification, and the public cost involved in developing and promoting the zones. Some information is also provided concerning the firms' attitudes toward the different incentives offered.

The monitoring study attempted to differentiate 
between the "gross effects," i.e., the increased economic activities within the zones themselves, and the "net effects," i.e., the spill-over effects on the level of economic activity in the surrounding areas (Tym, 1984, p. 10). While substantial data were compiled relating to the "gross effects," the "net effects" remain largely a matter of speculation.

Firms - During the first year following designation of the enterprise zones, 295 firms began operations in the British enterprise zones. During the second year, an additional 474 firms entered the zones, while 44 of the first-year firms either closed or transferred operations to sites outside the zone. The net total firms operating in the zones as of May 31, 1983, was 725 (Table 1). The distribution of second-year new firms, by type of industrial activity, is shown in Table 2. By broad classification, 52 percent of the firms were involved in some type of service, while 39 percent were involved in some aspect of manufacturing.

Of the 474 second-year firms, 444 could be identified by origin. The number of "new openings" versus the number of "movers" is shown in Table 3. "New openings" accounted for 63 percent of those 444 firms (59 percent of all second-year firms), while "movers" accounted for 37 percent. Among the movers, 86 percent moved from locations within the same county, and 53 percent moved from locations within the same district. Among the total 444 second-year firms of known origin, 32 percent moved into the zones from locations within the same county; 19 percent from locations within the same district.

Half of the incoming firms during the second year indicated that they definitely would not have located at their chosen site in the absence of the incentives provided by the enterprise zones. Another one-third, however, indicated that they would have chosen the same site anyway, and about one-sixth indicated that they might have possibly chosen that site anyway. The importance of the incentives, however, is quite revealing.

A sample of 105 firms were surveyed and the results are presented in Table 4 . When asked to identify the EZ or non-EZ incentives most important to the firm, most of the firms surveyed cited rate relief as important, although the majority of firms could not place any monetary value on that incentive. The monitoring report suggested that the psychological effect of rate relief was probably a more powerful influence on firms than the very substantial but unknown financial value (Tym, 1984, p. 143). Firms were much more aware of non-EZ measures such as rent concessions and grants than any of the other EZ measures (Tym, 1984, p. 76).
The monitoring report found that at least 75 percent of all the incoming firms would be operating in the same county in the absence of any EZ incentives, and at least 85 percent would be operating in the same Economic Planning Region. The primary impact of the enterprise zones has been to attract firms to a specific site within a fairly small district or within the planning region. Only one zone, the Corby zone, has shown any real tendency to attract long-distance mobile industry (Tym, 1984, pp. 89-90). The report also concluded that the firms attracted to the zones are very likely to displace local competition to a significant degree. (Tym, 1984, p. 144).

For developers of speculative buildings within the enterprises zones, the incentives provided by the 100 percent IBAs have been "particularly significant." One factor apparently playing an important role in the increased rate of development within the zones during the second year was the availability of serviced land. Generally, this has been created through publicly financed land preparation schemes, such as the projects undertaken by the Swansea City Council and the Welch Development Agency (Tym, 1984, p. 143).

Bromley and Morgan (1985) analyzed the industrial trends in Swansea before and after the enterprise zone was designated. Two trends that were well established were a tendency for firms to become smaller, i.e., a growing percentage of new firms were small; and an increasing percentage of firms engaged in services. After reviewing the developments through the first few years of the Swansea zone, Bromley and Morgan concluded that the principal effect of the enterprise zone has been to simply consolidate those well-established trends in a limited fashion. Thus, for proponents of enterprise zones who hoped that small manufacturing firms would emerge, the Swansea experience is only partly reassuring. Moreover, Bromley and Morgan found reasons to view the branch openings in a negative light, and noted that these enterprises on the whole have not fared as well as the new openings and transferred firms.

Jobs - In view of the unemployment problems that have plagued Britain in the 1980 s, the ability of the enterprise zones to generate job creations should be of special interest to policy analysts. The 251 first-year firms still operating at the end of May 1983 employed 3,030 workers. The 474 second-year firms employed an additional 5,035 , for a total employment by the 725 firms operating in the zones as of May 1983, of 8,065. The breakdown of jobs by enterprise zone is shown in Table 1.

The firms were predominantly small employers, e.g., 80 percent of the second-year firms employed 10 or 
less workers. Only 2 percent of the second-year firms (eight firms) employed between 50 and 100 workers, while just one firm employed more than 200 workers. In terms of employment distribution by type of industrial activity, 45 percent of the workers employed by the second-year firms were engaged in manufacturing activities; 10 percent in construction activities; and 45 percent in services.

Table 5 indicates the number of "new" jobs versus the number of "transferred jobs." The split between the two categories was virtually even--2,479 jobs were "transferred," 2,482 were due to "new openings." The source of the transferred jobs showed a somewhat less local emphasis than the source of transferred firms. Whereas 86 percent of all "movers" among the firms were from within the county (32 percent of all incoming firms), those firms accounted for only 67 percent of the transferred jobs (34 percent of all employment by second-year firms). While only 3 percent of all incoming second-year firms were "movers" from outside of the region, these firms accounted for 28 percent of all transferred jobs, and 14 percent of all the employment by second-year firms.

Public Cost - There appears to be a popular impression in the United States that enterprise zones offer a policy approach that leads to economic development of derelict areas at very little public cost. The relaxation of bureaucratic rules and reduction of taxes presumably will free private entrepreneurship of its shackles and the development projects will be forthcoming from the private sector. The British experience hardly bears that premise out as the initiating force has been the preparation of the land through reclamation projects and the provision of the necessary infrastructure. In addition, a number of zones, e.g., the Swansea zone, involved the initial construction of buildings by public authorities on a speculative basis. As noted above, the more rapid pace of development during the second year of the first-generation zones was attributed in substantial degree to the availability of good industrial sites.

Some crude data on public cost of the enterprise zone program over the two year period are provided by the monitoring report. Table 6 offers a summary statement of the public cost. The estimated value of the cost to the central government of compensating the local governments for property tax lost amounted to about 17 million pounds while the tax expenditure associated with the IBAs was estimated to be 38 million pounds. In addition, 38 million pounds were spent by local authorities on site assembly and preparation and another 40 million pounds on public development. The grand total for the two years came to 133 million pounds. Using the exchange rate of $\$ 2$ per pound, the dollar equivalent public cost was \$266 million.

Again using the crude estimation approach that we used in the Swansea case study, only about 12 percent of the total 8,075 jobs in the zones as of May 31, 1983 could be regarded as "created" by the presence of the zones. Thus, roughly 1,000 jobs were "created" at a public cost of $\$ 266$ million, or an approximate cost of $\$ 274,800$ per job created.

Adverse Effects on Property Values - One of the issues raised by the designation of the enterprise zones concemed the possible adverse effects on land values in the community outside of the zone. The evidence is very limited, but does seem to substantiate this fear to some degree. For example, industrial land values in sites near the Swansea zone decreased some 10 percent during the first year of its existence. Industrial parks located on the M4 motorway south of Swansea, and hence, further away from London and Birmingham, remained undersubscribed. Local officials in those areas tended to blame their problems on unfair competition from the Swansea zone. One neighboring council demanded an enterprise zone of its own as a defensive measure (The Economist, 1982).

Erickson and Syms (1986) have devised a scenario method for studying the effect of the enterprise zones on industrial rentals. They developed a full empirical study of the effects in only one case, the Salford/Trafford zone. While the data are highly questionable, it does appear that the zone designation created a dual local property market with distinctly different effects in the zone and the periphery. While real rental value of properties within the zone were declining in the late 1970 s, that trend has been sharply reversed after zone designation. Rental prices posted a significant real increase, reaching a maximum level by the end of the second year following zone designation. In contrast, Erickson and Syms found that industrial properties located on the periphery of the zone suffered a sharp decline in real rental prices in general and posted no recovery during the time period surveyed (Erickson and Syms, 1986, pp. 12-13).

EZs as Promotional Devices - Intangible benefits of enterprise zones as marketing tools to be used by local officials in promoting their economic development strategies have been warmly applauded by local administrators. The publicity associated with the Swansea zone's status as Britain's first zone was of considerable importance in terms of encouraging interested firms to inquire into possible zone locations. Within weeks following its designation, some 400 inquiries had been received from both large and small firms. It is interesting to note the nature of the 
advertisements placed by local authorities of areas with enterprise zones in the Financial Times' "Survey on Entserprise Zones" (Financial Times, 1983c). Generally, the enterprise zone itself was primarily an "eye catcher" in the ad, with heavy emphasis on other benefits available to firms operating in the community. For example, the Middlesbourgh ad listed its enterprise zone along with its special development area status, first class communications, EEC benefits, and various types of financial assistance schemes.

The image of enterprise zones as having more publicity value than any real influence on the investment decisions by business firms is further enhanced in an indirect fashion by the special surveys on small businesses that appeared in the The Economist and the Financial Times during 1983. (The European Community Designated 1983 as the Year of Small and Medium Sized Enterprises-EYSME) and consequently, most business/economic periodicals devoted some space to small businesses. Enterprise zones were virtually ignored. Rather, both surveys heavily stressed the various public assistance schemes for smaller firms, especially financial assistance programs, without any mention of the tax benefits or planning use regulations relief offered by enterprise zones. In Britain, the government's Enterprise Allowance Schemes, which provides a small weekly payment to unemployed persons starting their own businesses, the Small Engineering Firms Investment Scheme, and the Loan Guarantee Scheme received prime attention.

While the enterprise zone concept emphasizes free enterprise rather than government actions, as the monitoring report noted, "The marketing of the EZ as a whole is naturally a public responsibility as no other parties' interests span the whole zone." (Tym, 1984, p. 112). In some enterprise zones, e.g., the Swansea zone, special budgetary allocations were made to assure funds for marketing the zones. The monitoring report found that enterprise zones were promoted most successfully in those cases where the authorities linked assurances that land and sites would be available with their publicity efforts (Tym, 1984, p. 112).

\section{Summary}

What conclusions may be drawn from the British experience with enterprise zones? The first is that the British program is a far cry from the original concept zone program as it exists in Britain are worth noting. The program definitely demonstrates that an activist public policy supported by public funds and energetic and no doubt demonstrates the difficulty in getting an original concept manifested into policy through the political process. Yet it would be misleading to argue that because the actual program only faintly resembles the original concept at best, no real information is provided. Several firm conclusions about the enterprise public authorities can definitely influence location decisions by firms that are mobile and are seeking a site in a fairly well-defined area. If small areas are wellserviced by local authorities, heavily promoted, buttressed with a variety of regional assistance schemes and aprograms to aid business firms, financial problems, and offer escape from heavy property taxes, local firms being pushed from present sites will tend to choose sites in the designated areas.

But more importantly, from the original concern over jobs in inner-cities, enterprise zones appear to be a very inefficient policy approach. The British zones were, of course, designed more to bring about land development than to stimulate jobs. American proponents (Butler, 1984) have recognized this, and the American proponents for federal enterprise zone programs specifically aim at incentives to create jobs. But the British experience demonstrates once again that it is much more difficult to develop public policies that lead to the creation of new firms and new jobs than it is to simply influence the behavioral pattern of those what will exist anyway.

The public cost per job created has been quite high. The enterprise zones themselves influenced the location decision of firms only at the micro (intra-regional) level in most instances. Indeed, much of the development in the more successful zones can be attributed to strong recruiting efforts by local authorities and development agencies that did not emphasize zone benefits. The most successful zones benefited from assistance provided by several regional development programs. The economic incentives provided by the enterprise zones had only marginal effects on firms' investment and location decisions. Perhaps the greatest value of the enterprise zones has been in terms of the publicity benefits to the local communities.

\section{REFERENCES}

Armstrong, Harvey and Jim Taylor. Regional Economics and Policy Oxford: Phillip Allen Publishers Ltd., 1985.

Botham, R. and G. Loyd. "The Political Economy of Enterprise Zones, National Westminister Bank Quarterly Review, May 1983: 24-32.

Butler, Stuart M. Enterprise Zones: Greenlining the Inner Cities. New York: Universe Books, 1981.

Bromley, Rosemary D. F. and Richard Morgan. "The Effects of Enterprise Zones: Evidence from 
Swansea," Regional Studies: 19:5, (1985). 403-414.

The Director. "New Defenses for Business: Enterprise Zones," May (1985). 53-55.

The Economist. "Let a Thousand Factories Grow", March 29 (1980). 33.

"Hong Kong in Wales?," November 20

(1982a). 61.

, "Enterprise and Freedom," December 18

(1982b). 17-18.

"Britain's Small Businesses," July 13

(1983). 60-63.

Erickson, Rodney A. and Paul M. Syms. "The Effects of Enterprise Zones on Local Property Markets,"

Regional Studies 20:1 (1086). 1-14.

Europe: Magazine of the European Community, "Small Companies Get Special Breaks in Europe," March/ April (1984). 24-25.

Financial Times, "Reviving the Inner City by Removing Red Tape," July 30, 1980. "Enterprise Zones: A Questionable Start,"

August 24 (1981).

. "Survey--Small Business," May 3 (1983a).

"Survey--Wales," September 28 (1983b).

"EnterpriseZones--Survey," October18(1983c).

Ford, R. L., "GSOC and ESOP Alternatives to Enterprise Zones," Growth and Change, October (1983). 22-31.

Gunther, William D. and Charles G. Leathers "Enterprise Zones in U.S. Urban Policy: A Critical Look," Texas Business Review, July-August (1981).
Hall, P. "U.K. Enterprise Zones: Facts, Fantasies, and Opportunities," Financial Times, February 22 (1984). 13.

Hare, Paul. Planning the British Economy. London: Macmillian Publishers, Ltd. 1985.

Hawkins, B. M. 1094. "The Impact of the Enterprise Zone on Urban Areas," Growth and Change, January (1984). 35-40.

Howe, Sir G. "Liberating Free Enterprise: A New Experiment." Reprinted in New Tools for Economic Development, edited by G. Sternlieb and D. Listokin, Piscataway, N. J.: Center for Urban Policy Research, Rutgers University, 1981: 13-24.

Malone, J. "The Questionable Promise of Enterprise Zones: Lessons from England and Italy," Urban Affairs Quarterly, September (1982). 19-30.

Swansea City Council 1985a, Swansea Enterprise Park, Monitoring Report No. 13, (January 1985). , 1985b Swansea Enterprise Park, Monitoring Report, No. 15, (July) 1985. , 1985c Swansea Enterprise Park: Britain's Largest Enterprise Zone, 1985.

Swansea City Planning Department. "Lower Swansea Valley" (a brochure), 1983.

Tym, Roger and Partners. Monitoring Enterprise Zones: Third Year Report. London: Her Magesty's Stationary Office, 1985.

Vickerman, R. W. Urban Economics: Analysis and Policy. Oxford: Phillip Allan Publishers,Ltd.,1984.

Weiner, S. E. "Enterprise Zones as a Means of Reducing Structural Unemployment," Federal Reserve Bank of Kansas City Economic Review, March (1984). 3-16.

Table 1

Poet-Dexignation Firms and Jobs Amons

Britah Baterprise Zones: June 1981 - May 1983

\begin{tabular}{|c|c|c|c|}
\hline Enterprise Zone & Number of Firms & & Number of Jobs \\
\hline Salford/Trafford & 100 & & 1,052 \\
\hline Swansea & 81 & & 1,046 \\
\hline Wakefield & 16 & & 156 \\
\hline Clydebank & 144 & & 1,637 \\
\hline Dudley & 64 & & 523 \\
\hline Hartlepool & 34 & & 476 \\
\hline Corby & 63 & & 1,591 \\
\hline Tyneside & 61 & & 446 \\
\hline Speke & 31 & & 453 \\
\hline Ilse of Dogs & 77 & & 353 \\
\hline \multirow[t]{2}{*}{ Belfast } & 54 & & 332 \\
\hline & Total Firms: & Total Jobs: & 8,065 \\
\hline
\end{tabular}


Table 2

Distribution of New Firms by Type of Activity All Britich Enterprize Zones (Second Year)

\begin{tabular}{|c|c|c|}
\hline Industrial Activity & Number of Firms & Percentage \\
\hline \multicolumn{3}{|l|}{ Manufacturing: } \\
\hline \multicolumn{3}{|l|}{ Engineering and } \\
\hline Metal Working & 79 & $17 \%$ \\
\hline Other Manufacturing & 107 & $23 \%$ \\
\hline Total Manufacturing & 186 & $39 \%$ \\
\hline Construction & 42 & 9 \\
\hline \multicolumn{3}{|l|}{ Services: } \\
\hline \multicolumn{3}{|l|}{ Transportation and } \\
\hline Distribution & 148 & 31 \\
\hline Office-Based Services & 31 & 6 \\
\hline Other Services & 67 & 14 \\
\hline Total Services & 246 & $52 \%$ \\
\hline Public Administration & 1 & $=$ \\
\hline Total & 474 & $100 \%$ \\
\hline
\end{tabular}

Source: Roger Tym and Partners (1984), Monitoring Enterprise Zones: Year Three Report Table 5.2, p. 57.

Table 3

Origins of Second-Year Incoming Firms:

New Openings and Movers

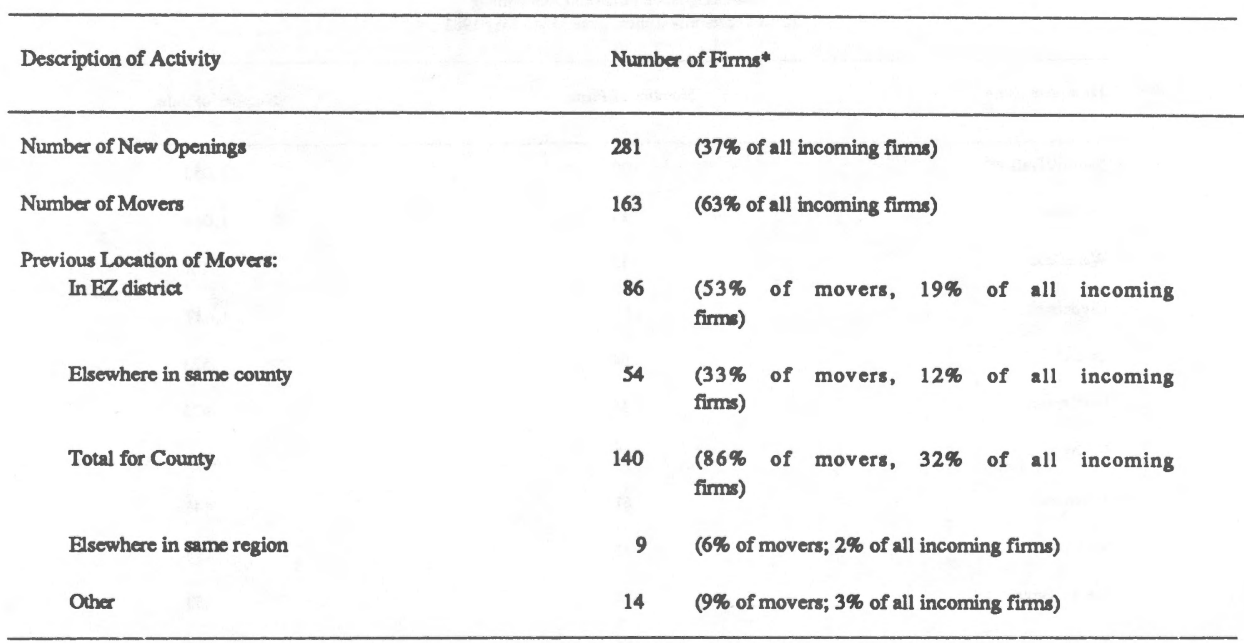

*The total firms included are only 444. Another 30 firms were of unknown origin.

Source: Roger Tym and Partners (1984), Monitoring Enterprise Zones: Yecr Three Report Table 5.4,p.58. 
Table 4

Firm's Citation of EZ and non-EZ

Incentives With Favorable Influence

(sample of 105 firms)

\begin{tabular}{lc}
\hline Incentives & No. of Mentions \\
\hline EZ Incentives: & 71 \\
Rates exemptions & 4 \\
IBAs & 1 \\
Relaxed planning controls & - \\
Development Land tax exemption & - \\
Quicker customs facilities & - \\
Recuced statistical surveys & - \\
Exemption from IrB requirements & \\
Non-EZ Incentives: & 8 \\
Rent concessions & 5 \\
Grants & 5 \\
Other & 17 \\
Not Answering & 105 \\
Total & \\
\hline
\end{tabular}

Source: Roger Tym and Partners (1984), Monitoring Enterpris Zones: Year Three Report, Table 5.18, p. 80.

Table 5

Source of Jobs Provided by Second-Year Firms

\begin{tabular}{|c|c|c|}
\hline Type of Activity & Number of Jobs & Distribution \\
\hline New Openings & 2,482 & (50\% of all employment) \\
\hline All Movers & 2,479 & (50\% of all employment) \\
\hline \multicolumn{3}{|l|}{ Previous Location: } \\
\hline EZ District & 959 & $\begin{array}{l}\text { (39\% of all transferred } \\
\text { jobs: } 19 \% \text { of total jobs) }\end{array}$ \\
\hline EZ County & 712 & $\begin{array}{l}\text { (29\% of all transferred } \\
\text { jobs; } 14 \% \text { of all jobs) }\end{array}$ \\
\hline Total County & 1,671 & $\begin{array}{l}\text { (67\% of all transferred } \\
\text { jobs; } 34 \% \text { of total jobs) }\end{array}$ \\
\hline $\begin{array}{l}\text { EZ Region } \\
\text { (excluding county) }\end{array}$ & 114 & $\begin{array}{l}\text { (5\% of transferred jobs; } 2 \% \\
\text { of total jobs) }\end{array}$ \\
\hline Other & 694 & $\begin{array}{l}\text { (28\% of transferred jobs; } \\
14 \% \text { of total jobs) }\end{array}$ \\
\hline
\end{tabular}

Source: Roger Tym and Partners (1984), Monitoring Enterprise Zones: Year Three Report, Table 5.4, p. 58, Tym and Partners. 
Table 6

Public Cost of British Enterprise Zones

First Generation Zones

(Through May 30, 1983)

\begin{tabular}{ll}
\hline Item & Estimated Cost \\
\hline Cost of Rate Relief & 16.8 million pounds \\
Cost of the IBAs & 38.0 million pounds \\
Public Development & 39.8 million pounds \\
Public Investment in Site & \\
\multicolumn{1}{c}{ Assembly and Preparation } & 38.3 million pounds
\end{tabular}

Source: Roger Tym and Partners (1984). Monitoring Enterprise Zone: Year Three Report, p. 101. 